\title{
Right ventricular myocardial infarction: echocardiographic evidence among patients with inferior wall myocardial infarction
}

\author{
Deveshwar Pandey, Bhrigu Raj Sood, Madan Lal Kaushik, Rajeev Bhardwaj, Ashok Sharma
}

\begin{abstract}
Abstrak
Infark ventrikel kanan yang terutama terjadi sebagai komplikasi infark inferior merupakan entitas penyakit tersendiri dimana dapat terjadi gangguan hemodinamik mayor. Pemeriksaan hemodinamik, elektrokardiografi (EKG), radionuklid angiografi dan ekokardiografi digunakan untuk mengetahui keterlibatan ventrikel kanan pada infark inferior. Infark ventrikel kanan terjadi pada 30 sampai 50\% kasus infark inferior. Kami telah melakukan penelitian pada 37 pasien dengan infark inferior akut (dengan metode non invasif) dengan tujuan menilai peranan ekokardiografi dalam diagnosis infark ventrikel kanan dan membandingkan sensitivitasnya terhadap EKG dan kriteria klinis. Pada ekokardiografi, 12 dari 37 pasien (32\%) menunjukkan keterlibatan ventrikel kanan. Tanda Kussmaul terjadi pada $27 \%$ pasien dan menunjukkan sensitivitas $50 \%$, spesifisitas $88 \%$, dan ketepatan prediksi $70 \%$. Hantaran prekordial kanan pada $E K G\left(V_{3} R\right.$ dan $\left.V_{4} R\right)$ mendeteksi infark ventrikel kanan pada $30 \%$ pasien dengan sensitivitas, spesifisitas dan ketepatan prediksi masing-masing sebesar $67 \%$, 88\%, dan 73\%. Gambaran ekokardiografi terdiri dari pembesaran ventrikel kanan dengan hipokinesia atau akinesia. Dilatasi dan disfungsi ventrikel kanan diperoleh dari besar relatif ventrikel kanan terhadap ventrikel kiri. Cara ini lebih sensitif dan spesifik dibandingkan gejala klinik dan EKG. (Med J Indones 2006; 15:94-9)
\end{abstract}

\begin{abstract}
Right ventricular myocardial infarction (RVMI) predominantly a complication of inferior wall myocardial infarction is a distinct clinical entity in which major hemodynamic disturbance may occur. Bedside hemodynamic measurement, electrocardiography, gated blood pool radionuclide angiography and echocardiography are used to identify right ventricular involvement in setting of inferior wall infarction. RVMI as assessed by various diagnostic methods accompanies 30 to 50\% of inferior wall infarction. We studied 37 consecutive patients of acute inferior wall infarction (by non invasive method) to determine echocardiographic evidence of RVMI and compared its sensitivity to electrocardiography and clinical criteria. On echocardiography 12 out of 37 patients (32\%) had right ventricular involvement. Kussmaul's signs was present in $27 \%$ of the patients and it had sensitivity of $50 \%$, specificity of $88 \%$ and predictive accuracy of $70 \%$. Right sided precordial leads $\left(V_{3} R-V_{4} R\right)$ on electrocardiography showed evidence of RVMI in $30 \%$ of patients with sensitivity, specificity and predictive accuracy of $67 \%, 88 \%$ and $73 \%$ respectively. Echocardiographic features included enlargement of right ventricle and hypokinesia or akinesia of right ventricular wall. Right ventricular dilatation and dysfunction is gained from relative right and left ventricular dimension on echocardiography. It is more sensitive and specific than clinical signs and ECG. (Med J Indones 2006; 15:94-9)
\end{abstract}

Keywords: Right ventricular myocardial infarction, inferior wall myocardial infarction, echocardiography, Kussmaul's sign

Isolated infarction of right ventricle is considered rare, whereas right ventricular myocardial infarction (RVMI) as an extension from left ventricular infarction occurs more commonly. RVMI is predominantly a complication of inferior wall myocardial infarction. Since the initial description of the syndrome of predominant right ventricular failure in some patients with inferior

Department of Cardiology, Indira Gandhi College, Shimla, HP India 171001 wall myocardial infarction by Cohn et $\mathrm{al}^{1}$, RVMI is now considered as distinct clinical entity in which major hemodynamic disturbance may occur.

The clinical triad of hypotension, clear lung fields, and elevated jugular venous pressure in a patient with inferior wall infarction is virtually pathognomic for RVMI. The reported reliability of clinical signs of right ventricular dysfunction in patients with inferior wall infarction varies widely. ${ }^{2}$ Several techniques have been suggested to identify right ventricular involvement in setting of inferior wall infarction 
which include bedside hemodynamic measurement, electrocardiography, technetium pyrophosphate scintigraphy, gated blood pool radionuclides angiography and echocardiography.

The most accurate technique is by hemodynamic evaluation, but this is invasive. Electrocardiographic evidence has proven a sensitive adjuvant to the diagnoses of RVMI in the form of ST changes in right sided leads. Sensitivity of this method has been limited by its transient appearance, as ST segment elevation disappears rapidly in patients with inferior wall myocardial infarction $(50 \%$ in 10 hours after onset of chest pain). ${ }^{3,4}$

Echocardiography has become a useful tool in the diagnosis of RVMI. The initial M-mode studies have demonstrated right ventricular dilatation as an increased ratio of right ventricular to left ventricular end diastolic dimension in patients with RVMI. Introduction of two dimensional echocardiography has allowed a better quantitative assessment. Abnormal findings include right ventricular asynergy and abnormal interventricular septal motion.

RVMI as assessed by various diagnostic methods accompanies inferior wall myocardial infarction in 30 to $50 \%$ of patients. The proper management of RVMI includes volume loading to maintain adequate right ventricular preload, inotropic support and maintenance of atrioventricular synchrony.,

Electrocardiographic (ECG) and clinical criteria to determine RVMI is transient, so our aim was also to compare the sensitivity of electrocardiography and clinical criteria to echocardiography in determining right ventricular myocardial infarction among patients with inferior wall myocardial infarction.

\section{METHODS}

The study was conducted in the department of medicine and department of cardiology, at Indira Gandhi Medical College, Shimla in 2001. Thirty seven consecutive patients of acute inferior wall myocardial infarction admitted in cardiac care unit were taken up for study. Patients satisfying two out of three criteria were included in the study.

1. Chest pain suggestive of angina lasting for more than thirty minutes.

2. Positive Troponin-T test after 6 hours of the onset of chest pain.
3. ECG evidence of evolving acute myocardial infarction in inferior leads II, III and aVF in the form of new Q waves or ST segment abnormalities (includes both STEMI and non-STEMI) or T inversion lasting for more than 24 hours.

Study subjects were evaluated clinically at the time of admission specifically for the presence of signs of right ventricular dysfunction. Serial ECG were recorded at an interval of 8 hours for 48 hours, including right sided precordial leads $\mathrm{V}_{4} \mathrm{R}$ to $\mathrm{V}_{8} \mathrm{R}$. ST elevation of $0.5 \mathrm{mv}$ was taken as an indication of right ventricular infarction.

Echocardiographic evaluation of the study subjects was done during admission. End diastolic dimensions were obtained for both ventricles in the minor axis. The end diastolic right ventricle/left ventricle dimensional ratio was calculated. Elevation of the ratio suggested relative dilatation of the right ventricle. Real time two dimensional echocardiography was performed through standard para-sternal long and short axis views as well as four chamber views from apical and subcostal positions. Wall motion was qualitatively classified as normal (limited systolic inward motion), akinetic (lack of systolic inward motion) or dyskinetic (outward motion of endocarium during systole).

Volumes at end diastole and end systole were estimated for left ventricle and right ventricle by using single plane Simpson's rule. Right ventricular enlargement was considered to be present when the end diastolic ratio between the right and left ventricle was greater than 0.5 . In an attempt to relate abnormal wall motion to global function, injection fraction (EF) was estimated from these volumes.

Ejection fraction $=\frac{(\text { End diastolic volume }- \text { End systolic volume })}{\text { End diastolic volume }} \times 100$

Though none of the echocardiographic method is accurate for estimation of right ventricular ejection fraction, however for comparison between the patients with and without right ventricular infarction Simpson's method was used.

One two dimensional echocardiography patients with evidence of abnormal segmental wall motion of right ventricular free wall will be classified in group 1 and 
rest of the patients in group 2. These two groups will be compared for clinical profile, clinical signs, ECG and echocardiographic parameters.

Patients in group 1 with RVMI will be compared with group 2 without RVMI so as to know the significance of age, smoking, hypertension and diabetes mellitus in addition to echocardiographic parameters. Values are quoted as mean \pm standard deviation. Significance of difference with in a group and between two groups was assessed by paired and unpaired tests, respectively. A probability $(\mathrm{p})$ value less than 0.05 was considered significant.

\section{RESULTS}

In the present study, 37 patients with acute inferior wall myocardial infarction were included. The time period of hospitalization following the onset of symptoms varied from 1 to 72 hours. However, the maximum patients $(27 \%)$ were hospitalized with in first six hours following chest pain. Out of 37 patients, $20(54.05 \%)$ were smokers, $8(21.6 \%)$ were hypertensives, $5(13.5 \%)$ were diabetic. Family history of coronary artery disease was present in $4(10.8 \%)$ patients. Table 1 shows the characteristics of the patients with RVMI.

Clinically, 8 of 37 patients had raised JVP. Six patients with raised JVP also had echocardiographic evidence of RVMI. Ten of 37 patients demonstrated positive Kussmaul's sign (late inspiratory increase in JVP) and seven of these ten patients showed echocardiographic evidence of RVMI. Of the 27 patients without positive Kussmaul's sign, 5 had echocardiographic finding suggestive of RVMI as shown in table 2. These clinical findings were present within 48 hours of admission and disappeared in all patients by the time of discharge.

Table 1. Clinical features in group I patients at the time of admission

\begin{tabular}{cccccccccc}
\hline $\begin{array}{c}\text { Sr. } \\
\text { No. }\end{array}$ & Age & Sex & $\begin{array}{c}\text { Ad. ACP. } \\
\text { (hours) }\end{array}$ & BP & JVP & Kus. sign. & RVS-3 & $\begin{array}{c}\text { Changes } \\
\left(\mathrm{V}_{3} \mathrm{R}-\mathrm{V}_{4} \mathrm{R}\right)\end{array}$ & $\begin{array}{c}\text { Throm. } \\
\text { Therapy }\end{array}$ \\
\hline 1. & 52 & $\mathrm{M}$ & 10 & $96 / 70$ & - & - & - & + & given \\
2. & 60 & $\mathrm{M}$ & 48 & $100 / 60$ & $\uparrow$ & + & + & + & - \\
3. & 55 & $\mathrm{M}$ & 18 & $140 / 80$ & - & - & - & + & - \\
4. & 57 & $\mathrm{M}$ & 8 & $90 / 60$ & $\uparrow$ & + & + & + & given \\
5. & 45 & $\mathrm{M}$ & 12 & $110 / 70$ & - & - & - & - & - \\
6. & 55 & $\mathrm{M}$ & 24 & $94 / 70$ & $\uparrow$ & + & + & + & given \\
7. & 65 & $\mathrm{M}$ & 4 & $90 / 60$ & $\uparrow$ & + & + & + & - \\
8. & 51 & $\mathrm{M}$ & 18 & $100 / 70$ & - & + & + & + & given \\
9. & 55 & $\mathrm{M}$ & 30 & $86 / 60$ & $\uparrow$ & + & + & - & given \\
10. & 55 & $\mathrm{~F}$ & 10 & $90 / 60$ & $\uparrow$ & + & + & + & given \\
11. & 73 & $\mathrm{M}$ & 72 & $110 / 70$ & - & - & - & - & - \\
12. & 69 & $\mathrm{M}$ & 36 & $130 / 80$ & - & - & - & - & - \\
\hline
\end{tabular}

Abbreviations :

Ad. ACP. Admission after chest pain

BP Blood pressure

JVP Jugular venous pressure

Kus. sign Kussmaul's sign

RVS-3 Right ventricular third heart sound

Throm. Thrombolytic therapy 
Table 2. Comparison of detection of right ventricular infarction by echocardiography and presence of Kussmaul's sign in these patients

\begin{tabular}{lccc}
\hline & \multicolumn{2}{c}{ Echocardiography } \\
\cline { 3 - 4 } & & + ve & - ve \\
\hline \multirow{2}{*}{ Kussmaul's sign } & $+\mathrm{ve}$ & 7 & 3 \\
& $-\mathrm{ve}$ & 5 & 22 \\
\hline
\end{tabular}

Abbreviations :

+ve : Right ventricular infarction

-ve : No right ventricular infarction

Echocardiographic evaluation of patients was done in 72 to 96 hours after onset of symptoms. Of these 37 patients, 12 patients showed segmental wall motion abnormality of right ventricular free wall on two dimensional echocardiography. These 12 patients were compared with the rest 25 patients. Echocardiographic features of group-I $(n=12$, patients with right ventricular myocardial infarction on echocardiography) and group-II $(n=25$, patients without right ventricular myocardial infarction on echocardiography) are summarized in table 3. Right ventricular end diastolic dimension in group-I ranged from 20 to $30 \mathrm{~mm}$ with mean of $24.1 \pm 4.1 \mathrm{~mm}$ whereas in group-II it ranged from 11 to $30 \mathrm{~mm}$ with a mean of $17.9 \pm 4.1 \mathrm{~mm}$. Mean right ventricular end diastolic dimension was significantly greater in group-I than in group-II $(p<.005)$. The ratio of right ventricle/left ventricle end diastolic dimension (RVED/LVED) in group-I ranged from 0.40 to 0.76 with a mean of $0.54 \pm .10$, whereas in group-II it ranged from 0.25 to 0.63 with a mean of $0.39 \pm .09$. The RVED/LVED ratio was significantly greater in group-I than in group-II $(\mathrm{p}<.001)$. The right ventricular ejection fraction (RVEF) ranged from $25 \%$ to $42 \%$ with a mean of $39.9 \pm 6.3 \%$ in group-I whereas in group-II it ranged from $30 \%$ to $71 \%$ with a mean of $52 \pm 7.4 \%(\mathrm{p}<.001)$.

On two dimensional echocardiography right ventricular end diastolic volume in group-I ranged from 27 to $70 \mathrm{~cm}^{3}$ with a mean of $42.1 \pm 14.5 \mathrm{~cm}^{3}$. In group-II it ranged from 15 to $66 \mathrm{~cm}^{3}$ with a mean of $26.8+11.1 \mathrm{~cm}^{3}$. There was significant difference in group-I than in group-II $(\mathrm{p}<.001)$. The right and left ventricular end diastolic volume ratio (RVED/LVEDV) was 0.50 to 1.14 with a mean of $0.65 \pm 0.22$ in groupI and 0.26 to 1.17 in group-II with a mean of $0.42 \pm$ $0.18(\mathrm{p}<.005)$ in two groups.
Out of 37 patients 11 patients had evidence of RVMI on ECG. While eight patients with echocardiographic evidence of RVMI had ECG evidence of RVMI, three patients (12\%) had changes suggestive of RVMI on ECG, but not the echocardiographic evidence of RVMI as shown in table 4.

Table 3. Echocardiographic profile in group I and group II patients

\begin{tabular}{|c|c|c|c|}
\hline Parameter & Group I & Group II & $\mathrm{P}$ value \\
\hline & $\mathrm{RV} \pm \mathrm{VE}$ & $R V-V E$ & \\
\hline RVED & $24.16+4.10$ & $17.96+4.15$ & $<.001$ \\
\hline LVED & $44.83+7.66$ & $45.72+6.88$ & N.S. \\
\hline RVED/LVED & $.54+.10$ & $.39+.9$ & $<.001$ \\
\hline RV & $42.16+14.57$ & $26.80+11.17$ & $<.001$ \\
\hline LV & $68.25+22.21$ & $66.16+22.26$ & N.S. \\
\hline $\mathrm{RV} / \mathrm{LV}$ & $65+.22$ & $.41+.18$ & $<.005$ \\
\hline RVEF & $39.91+6.30$ & $52+7.48$ & $<.001$ \\
\hline LVEF & $58.33+9.23$ & $55.20+7.58$ & N.S. \\
\hline
\end{tabular}

Abbreviations :

RVED Right ventricular end diastolic dimension

LVED Left ventricular end diastolic dimension

RV Right ventricular end diastolic volume

LV Left ventricular end diastolic volume

Table 4. Comparison of detection of right ventricular infarction by echocardiography and electrocardiography

\begin{tabular}{lccc}
\hline & & \multicolumn{2}{c}{ Echocardiography } \\
\cline { 3 - 4 } & & $+\mathrm{ve}$ & $-\mathrm{ve}$ \\
\hline \multirow{2}{*}{ Electrocardiography } & $+\mathrm{ve}$ & 8 & 3 \\
& $-\mathrm{ve}$ & 4 & 22 \\
\hline
\end{tabular}

Abbreviations :

+ve : Right ventricular infarction

-ve : No right ventricular infarction

\section{DISCUSSION}

Evaluation of risk factor profile including smoking, hypertension, diabetes and family history of coronary artery disease had no significant difference between the patients with or without RVMI.

The bedside diagnosis of right ventricular myocardial infarction has been based on recognition of severe right ventricular dysfunction with resultant right sided heart failure. The clinical recognition has thus been 
limited to cases in which right ventricular involvement has been very extensive. In our study there was $27 \%$ incidence of Kussmaul's sign (late inspiratory increase in JVP). The presence of this sign in patients with inferior wall myocardial infarction predicted RVMI on echocardiography with sensitivity of $58 \%$, specificity of $88 \%$ and predictive accuracy of $70 \%$. In a study by Bellamy et al positive Kussmaul's sign had sensitivity, specificity and predictive accuracy of 59\%, $89 \%$ and $84 \%$ respectively in predicting right ventricular dysfunction on gated blood pool study. ${ }^{8}$

In our study we evaluated sensitivity, specificity and predictive accuracy of right sided precordial leads in detecting RVMI on echocardiography. Thirty percent of patients with inferior wall MI had evidence of RVMI on right sided precordial leads. It had sensitivity of $67 \%$, specificity of $88 \%$ and predictive accuracy of $73 \%$ in predicting RVMI on echocardiography. The present study has suggested that right sided precordial leads are less accurate than echocardiography in detecting RVMI. This may relate ot the fact that wall motion abnormalities persists for days while ECG abnormalities are transient which may resolve. The diagnostic accuracy of right precordial ST segment elevation is considered to be greatest during first 10 hours after an acute infarction ${ }^{9}$ but only $40 \%$ of the patients reported to hospital with in 10 hours after onset of chest pain in the present study.

In the present study $32 \%$ of patients had an evidence of RVMI on echocardiography. The incidence of right ventricular involvement was $40 \%$ in the study by Bellamy et al using echocardiography, whereas it was $44 \%$ when gated blood pool study (GBPS) was used. Sharp et al found that RVED and RVED/LVED ratio to be greater in patients with RVMI complicating inferior wall myocardial infarction. ${ }^{10}$ In two dimensional echocardiography evaluation of patients with RVMI complicating inferior wall myocardial infarction Bodh et al observed that right ventricular dysfunction was associated with right ventricular enlargement and abnormal wall motion. ${ }^{11}$ In our study, $32 \%$ of patients with abnormal right ventricular wall motion revealed greater right ventricular end diastolic dimension then the 25 patients without RVMI with a mean of $24.1 \mathrm{~mm}$ as compared to $17.9 \mathrm{~mm}$. RVED/LVED was also greater in group-I with a mean of $0.54 \pm 10$ as compared to group-II with a mean of $0.39 \pm .09$ suggesting right ventricular enlargement. On two dimensional echocardiography RV/LV end diastolic volume ratio was greater than 0.5 both in long and short axis planes suggestive of right ventricular enlargement.

It is concluded that right ventricular myocardial infarction is common after inferior myocardial infarction occuring in about one third of patients. Two dimensional echocardiography is helpful in detecting patients with right ventricular dysfunction after inferior myocardial infarction.

Right ventricular myocardial infarction complicating inferior wall myocardial infarction has been identified by ECG with the right precordial leads $\left(\mathrm{V}_{3} \mathrm{R}-\mathrm{V}_{6} \mathrm{R}\right)$. Echocardiography is very useful in detecting right ventricular myocardial infarction in patients with inferior wall myocardial infarction. It is more sensitive and specific than clinical signs and ECG. It may pict up some cases missed by the above methods. Indirect evidence of right ventricular dilatation and dysfunction is gained from relative right ventricular and left ventricular dimensions on echocardiography. So all the patients of inferior wall MI should be subjected to early echocardiography to determine the presence of RVMI, as the management of those with or without RVMI is different, and so is the prognosis.

\section{REFERENCES}

1. Cohn JN, Guhia NH, Broder MI, Limascz. Right ventricular infarction; clinical and hemodynamic features. Am J Cardiol 1974; 33:209-14.

2. Weinshel AJ, Ismer JM, Solem ON, Kenstam MA. The coronary anatomy of right ventricular myocardial infarction: relationship between the site of right coronary artery occlusion and origin of the right ventricular free wall branches. Circulation 1983; 68:suppl III:35.

3. Charles H. Croft, Pascal Nicord et al. Detection of acute right ventricular infarction by right precordial electrocardiography. Am J Cardiology 1982; 50:421-7.

4. Braat SH, Brayada P, Dendulk K. Van Omen V, Wellens HJJ. Value of lead V4R for recognition of the infarct coronary artery in acute inferior myocardial infarction. Am J Cardiol 1984; 53:1538-41.

5. Bellamy GR, Ramessen HN. Value of 2 DE, ECG and clinical signs in detecting right ventricular myocardial infarction. Am Heart J 1986; 112:304-9.

6. Lopez Sendon J, Goicia Fernandiz MA, Coma Camella I, Yanjuela MM, Bammuelos F. Symental right ventricular function after acute myocardial infarction, two dimensional echocardiographic study in 63 patients. Am J Cardiol 1983; 51:390-6.

7. Haji SA, Movahed A. Right ventricular infarction diagnosis and treatment. Clin Cardiol 2000; 23(7):473-82. 
8. Setaro JF, Cabin HS. Right ventricular infarction. Clin Cardiol 1992; 10(1):69-90.

9. Braat SH, Brugada P, Dizwann C, Coenegracht JM, Wellens HJ. Value of electrocardiogram in diagnosing right ventricular involvement in patients with an acute inferior myocardial infarction. Br Heart J. 1983; 49:36872.

10. Jugdutt BI, Sussex BA, Siraram CA, Rasall RE. Right ventricular infarction: Two dimensional echocardiographic evaluation. Am Heart J. 1984; 107(3):505-18. 